DOI: $10.15193 /$ zntj/2018/114/217

\author{
BARTŁOMIEJ ZIENIUK, AGATA FABISZEWSKA
}

\title{
RYBY ORAZ ODPADY RYBNE JAKO ŹRÓDŁO SKŁADNIKÓW BIOAKTYWNYCH ORAZ SUROWIEC DLA PRZEMYSLU ENERGETYCZNEGO
}

\begin{abstract}
Streszczenie
Celem niniejszej pracy była charakterystyka mięsa ryb oraz odpadów przemysłu rybnego jako źródła cennych składników odżywczych oraz surowca dla przemysłu energetycznego. Mięso ryb i przetwory rybne są ważnym elementem zróżnicowanej diety. Ryby i odpady rybne mogą być źródłem wielonienasyconych kwasów tłuszczowych omega-3 - kwasu dokozaheksaenowego (DHA) i eikozapentaenowego (EPA), czyli związków wywierających pozytywny wpływ na organizm człowieka. W technologii żywności stosuje się dodatki funkcjonalne pochodzące z ryb, w tym żelatynę rybną różniącą się właściwościami fizykochemicznymi od żelatyny wieprzowej, a także witaminy rozpuszczalne w thuszczach oraz barwniki karotenoidowe o działaniu przeciwutleniającym. Z ryb mogą być także izolowane peptydy wykazujące przeciwdrobnoustrojowe oddziaływanie na różne gatunki bakterii Gram-dodatnich i Gram-ujemnych. W pracy wskazano również na możliwość wykorzystania poprodukcyjnych odpadów rybnych do pozyskiwania składników cennych pod względem żywieniowym. Oprócz wykorzystania odpadów rybnych do produkcji pasz i mączek rybnych, olejów oraz kiszonek, jak również hydrolizatów białkowych jako przypraw w kuchni azjatyckiej, możliwe jest ich wykorzystanie w przemyśle energetycznym, m.in. do produkcji paliwa ciekłego typu biodiesel lub do produkcji biogazu. W pracy omówiono także aspekt bezpieczeństwa spożywania mięsa ryb, które mogą zawierać szkodliwe lipofilowe związki organiczne oraz metale ciężkie kumulowane przez te zwierzęta w środowisku bytowania, czyli w zanieczyszczonych słodkich i słonych wodach.
\end{abstract}

Słowa kluczowe: ryby, odpady rybne, wielonienasycone kwasy thuszczowe (PUFA - polyunsaturated fatty acids), składniki bioaktywne, biodiesel, biogaz

\section{Wprowadzenie}

Mięso ryb jest bardzo wartościowym produktem spożywczym, będącym źródłem tłuszczu, w tym długołańcuchowych wielonienasyconych kwasów tłuszczowych, jak

Mgr inż. B. Zieniuk, dr inż. A. Fabiszewska, Katedra Chemii, Wydz. Nauk o Żywności, Szkoła Główna Gospodarstwa Wiejskiego w Warszawie, ul. Nowoursynowska 159 C, 02-776 Warszawa.

Kontakt:agata_fabiszewska@sggw.pl 
również łatwo przyswajalnych białek o korzystnym składzie aminokwasowym, składników mineralnych oraz witamin A, D i E [2, 18, 38]. Zawartość wymienionych związków chemicznych jest zróżnicowana i zależy od takich czynników, jak: gatunek ryby, jej wiek, rodzaj spożywanego pokarmu czy miejsce żerowania. Ponadto pozytywny wpływ na zdrowie człowieka, wynikający ze spożywania ryb i przetworów rybnych, jest uzależniony od porcji tych produktów w codziennej diecie oraz od jakości i stopnia przetworzenia surowców.

Celem niniejszej pracy była charakterystyka mięsa ryb oraz odpadów przemysłu rybnego jako źródła cennych składników funkcjonalnych oraz surowca m.in. dla przemysłu energetycznego.

\section{Charakterystyka przemysłu rybnego w Polsce}

Gospodarka morska obejmuje m.in. rybołówstwo i przetwórstwo rybne. Ten sektor gospodarki stanowi jedną z najmniejszych dziedzin przemysłu. Wskazuje na to mała liczba podmiotów gospodarczych, których w roku 2015 było 14,1 tys., co stanowiło jedynie $0,3 \%$ wszystkich podmiotów, a liczba zatrudnionych wynosiła w $2015 \mathrm{r}$. 93,7 tys. ( $0,7 \%$ ogółu) [7].

Największe połowy ryb oraz skorupiaków i mięczaków w Polsce odnotowywano w latach 70. i 80. XX wieku. Od roku 1980 połowy ryb morskich zmniejszają się systematycznie. W roku 1985 wynosiły one 652 tys. ton, w $1990-430$ tys. ton, a w 2000 - 200 tys. ton. Po 2010 r. wielkość połowów organizmów wodnych plasuje się na zbliżonym poziomie i w 2015 roku wynosiła 187 tys. ton [6, 7]. Czynnikami wpływającymi bezpośrednio na gospodarkę rybną jest dostępność surowca, potencjał floty i przemysłu rybnego oraz administracja i organizacja rynku rybnego [19].

Do ryb najczęściej poławianych przez polskich rybaków w 2015 roku należały: szproty, śledzie, ostroboki i dorsze. Stanowiły one ponad 85 \% masy połowów. Ryby najczęściej poddaje się przetwarzaniu. Największy udział w rynku przetworów rybnych stanowią konserwy, marynaty i prezerwy rybne, których produkuje się ponad 150 tys. ton rocznie [7]. Na terenie Polski funkcjonuje obecnie 68 podmiotów gospodarczych zajmujących się przetwórstwem i konserwowaniem ryb oraz bezkręgowców morskich. Wartość produkcji sprzedanej tych wyrobów w 2015 roku wynosiła 8,9 mld złotych, co stanowiło 0,9 \% wartości wszystkich wyrobów przemysłowych i 5,4\% wartości artykułów spożywczych [8].

\section{Wielonienasycone kwasy tluszczowe w tluszczu rybnym}

Tłuszcz w rybach gromadzi się głównie w mięśniach, pod skórą oraz w wątrobie i gonadach [33]. Tłuszcz rybny stanowi źródło wielonienasyconych kwasów tłuszczowych (ang. polyunsaturated fatty acids, PUFA), niezbędnych do prawidłowego funkcjonowania organizmu. Najczęściej spotykanymi PUFA w rybach są kwasy z szeregu 
omega-3 - kwas eikozapentaenowy (EPA) i kwas dokozaheksaenowy (DHA) - rys. 1. Na przykład w oleju śledziowym stężenie kwasu EPA wynosi 14 \%, a zawartość DHA dochodzi do $11 \% \mathrm{w}$ odniesieniu do sumy wszystkich kwasów thuszczowych w tym oleju [15].

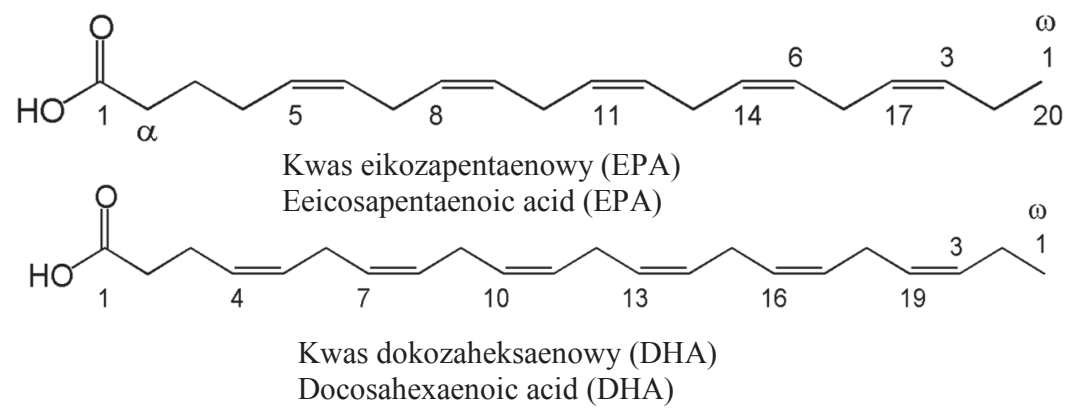

Rys. 1. Wielonienasycone kwasy thuszczowe występujące w oleju rybnym

Fig. 1. Polyunsaturated fatty acids occurring in fish oil

Produkty spożywcze zawierające kwasy omega-3 mogą być zaliczane do tzw. żywności funkcjonalnej, czyli żywności wywierającej pozytywny i potwierdzony klinicznie wpływ na zdrowie człowieka, jego stan umysłu i sprawność fizyczną [20]. Cząsteczki kwasów tłuszczowych z grupy omega-3 wchodzą w skład błon komórkowych oraz odgrywają rolę $w$ procesach przeciwzapalnych. Niższa częstość zapadania na choroby serca jest obserwowana np. w Japonii, czyli kraju o wysokim spożyciu ryb [30]. W zaleceniach amerykańskie oraz europejskie towarzystwa kardiologiczne rekomendują spożycie $1 \mathrm{~g}$ kwasów EPA i DHA dziennie w profilaktyce oraz wspomaganiu leczenia po zawale mięśnia sercowego [32]. Ponadto znaczne ilości DHA znajdują się w mózgu i siatkówce oka człowieka [35] oraz odgrywa on kluczową rolę w rozwoju mózgu w okresie pre- i postnatalnym [25].

Spożywanie wielonienasyconych kwasów tłuszczowych zawartych w rybach, bezkręgowcach morskich i przetworach z organizmów morskich przysparza niewątpliwie wielu korzyści zdrowotnych. Konsumpcja mięsa ryb oraz tłuszczów rybnych może jednak stwarzać ryzyko spożycia toksycznych ksenobiotyków, np. metali ciężkich, polichlorowanych bifenyli (PCB), pozostałości pestycydów chloroorganicznych czy polichloropochodnych dioksyn (PCDD) i furanów (PCDF). W badaniach, które prowadzili Bordajandi i wsp. [3], oceniono zawartość wybranych ksenobiotyków w mięśniach pstrąga, węgorza i brzany. Mięśnie węgorza zawierały najwięcej metali ciężkich, jak i pozostałych badanych związków organicznych (PCB i DDT - insektycydów z grupy polichlorowanych węglowodorów), lecz stężenia metali nie przekroczyły dozwolonych poziomów zanieczyszczeń [3]. Marcotrigiana i Storelli [21] wykazali, 
że zawartość lipofilowych ksenobiotyków w tuszach ryb jest tym większa, im większa jest w nich zawartość tkanki tłuszczowej. Podobne badania prowadzili Szlinder-Richert i wsp. [37], którzy oznaczyli zawartość składników odżywczych oraz zanieczyszczeń chemicznych, m.in. metali ciężkich, pozostałości leków weterynaryjnych, barwników oraz PCB, PCDD i PCDF w tkankach mięśniowych 9 popularnych na polskim rynku gatunków ryb pochodzących z Morza Bałtyckiego, hodowli na terenie Polski oraz ryb sprowadzanych z Chin i Wietnamu. Analizowane gatunki ryb były bogatym źródłem aminokwasów i różniły się stopniem zanieczyszczeń. W tkankach mięśniowych łososia i śledzia bałtyckiego stwierdzono przekroczenie zawartości PCDD, PCDF i dl-PCB (ang. dioxin-like polychlorinated biphenyls) ponad dopuszczalne limity. W przypadku pozostałych ksenobiotyków wykryte stężenia związków nie stanowiły zagrożenia dla zdrowia konsumentów [37].

W trosce o bezpieczeństwo konsumentów Światowy Fundusz na Rzecz Przyrody (ang. World Wide Fund for Nature, WWF) co roku publikuje poradnik o rybach i owocach morza zatytułowany: "Jaka ryba na obiad?" [11]. Poradnik stworzono, aby wesprzeć przeciętnych konsumentów w podejmowaniu odpowiednich decyzji żywieniowych.

\section{Żelatyna rybna}

Żelatyna jest białkiem zwierzęcym otrzymywanym ze skór i/lub kości pochodzenia wieprzowego, wołowego i rybnego [15]. Ten hydrokoloid produkuje się z wykorzystaniem metod chemiczno-termicznych w wyniku częściowej hydrolizy kolagenu białka o rozbudowanej strukturze, którego zawartość w skórze zwierząt wynosi ok. 20 \% [40]. Żelatynę szeroko wykorzystuje się do produkcji żywności, farmaceutyków, kosmetyków czy w fotografii [13]. Jej skład aminokwasowy jest zbliżony do składu kolagenu. W łańcuchu aminokwasowym białka występuje powtarzająca się tripeptydowa sekwencja: Gly-X-Y, gdzie oprócz glicyny (Gly), X to najczęściej prolina, a Y to hydroksyprolina [15].

Popyt na żelatynę wzrasta od lat, a dane z 2008 roku wskazują, że jej roczna produkcja wynosiła 326 tys. ton, przy czym $46 \%$ produkcji stanowiła żelatyna ze skór wieprzowych, a 29,4 \% - białka pochodzenia bydlęcego [13]. W wielu krajach zabroniono używania żelatyny wołowej (bydlęcej) w związku z epidemią gąbczastej encefalopatii bydła (BSE). Białko to nie jest również spożywane przez osoby na diecie wegetariańskiej i wegańskiej, dlatego w przemyśle spożywczym coraz częściej wykorzystuje się hydrokoloidy pochodzenia roślinnego, mikrobiologicznego lub ekstrakty z wodorostów $[15,40]$.

Żelatyna rybna różni się od żelatyny wieprzowej i bydlęcej głównie pod względem temperatury topnienia, żelowania i wytrzymałości żelu. Uważa się, że na te właściwości ma wpływ skład aminokwasowy, a w szczególności zawartość proliny i hy- 
droksyproliny. Oba aminokwasy tworzą wiązania wodorowe odpowiedzialne za stabilizację III-rzędowej struktury kolagenu. Im mniejsza zawartość proliny i hydroksyproliny, tak jak ma to miejsce w przypadku żelatyny rybnej, tym niższa jest temperatura topnienia i żelowania [26].

Produkcja żelatyny z odpadowych skór rybnych to jeden z najlepszych sposobów na ich zagospodarowanie [13]. Żelatyna wyprodukowana $\mathrm{z}$ ryb żyjących $\mathrm{w}$ zimnych wodach nie żeluje w temperaturze pokojowej - temperatura jej żelowania wynosi ok. $8 \div 10{ }^{\circ} \mathrm{C}$, dlatego może znaleźć zastosowanie w produktach mrożonych lub chłodzonych, gotowych do spożycia po wyjęciu z lodówki lub po rozmrożeniu, a także w produktach suszonych i mikrokapsułkowanych. Jej zastosowanie ograniczają jedynie słabsze właściwości reologiczne w porównaniu z żelatyną wieprzową i wołową [13].

\section{Inne bioaktywne składniki znajdujące się w rybach}

Wśród bioaktywnych związków chemicznych znajdujących się w rybach wymienić należy tokoferole (witamina E) o właściwościach przeciwutleniających. W grupie tokoferoli wyróżnia się: $\alpha$-, $\beta$-, $\gamma$ - i $\delta$-tokoferol oraz $\alpha$-, $\beta$-, $\gamma$-, $\delta$-tokotrienol, z czego w rybach występuje głównie $\alpha$-tokoferol (rys. 2). Zróżnicowanie zawartości witaminy $\mathrm{E}$ w tkankach ryb wynika głównie z różnic w składzie ich pokarmu, gdyż ryby nie są zdolne do syntezy tokoferoli [36].

Inną, również interesującą grupą składników bioaktywnych są karotenoidy. Podobnie jak w przypadku witaminy E, nie są syntetyzowane przez ryby, lecz pobierane przez nie wraz z pokarmem. Kumulowane są najczęściej w skórze, mięśniach, ikrze, wątrobie i oczach. Oprócz powszechnie występującego w organizmach morskich $\beta$-karotenu w różnych częściach anatomicznych ryb pojawia się również astaksantyna i fukoksantyna [1].

Astaksantyna jest ksantofilem o zdolnościach do neutralizacji wolnych rodników i innych utleniaczy (rys. 2). W wielu badaniach wykazano jej zdolność do obniżania stresu oksydacyjnego, stężenia białka C-reaktywnego (CRP) czy innych markerów stanu zapalnego. Ponadto obecność astaksantyny wpływała na obniżenie stężenia triacylogliceroli w surowicy krwi oraz na poprawę ostrości widzenia [14]. Fukoksantyna to ksantofil o brązowej barwie, mający silne działanie przeciwutleniające (rys. 2). Dodatkowo potwierdzony jest wpływ tego związku na obniżanie masy ciała, zwiększanie oporności na insulinę i obniżanie poziomu glukozy we krwi [1].

Ważnymi dla organizmu człowieka związkami występującymi w tkankach ryb są skwalen i sterole. Skwalen to wielonienasycony węglowodór zaliczany do grupy terpenów (rys. 2). Duże ilości tego węglowodoru znajdują się w oleju z wątroby rekina, a także w oliwie z oliwek z pierwszego tłoczenia i w oleju z amarantusa. Skwalen jest prekursorem cholesterolu i innych steroli. Wykorzystywany jest w przemyśle kosme- 
tycznym, a także w medycynie tradycyjnej w Japonii i Azji Południowo-Wschodniej w chorobach skóry i wątroby [16].
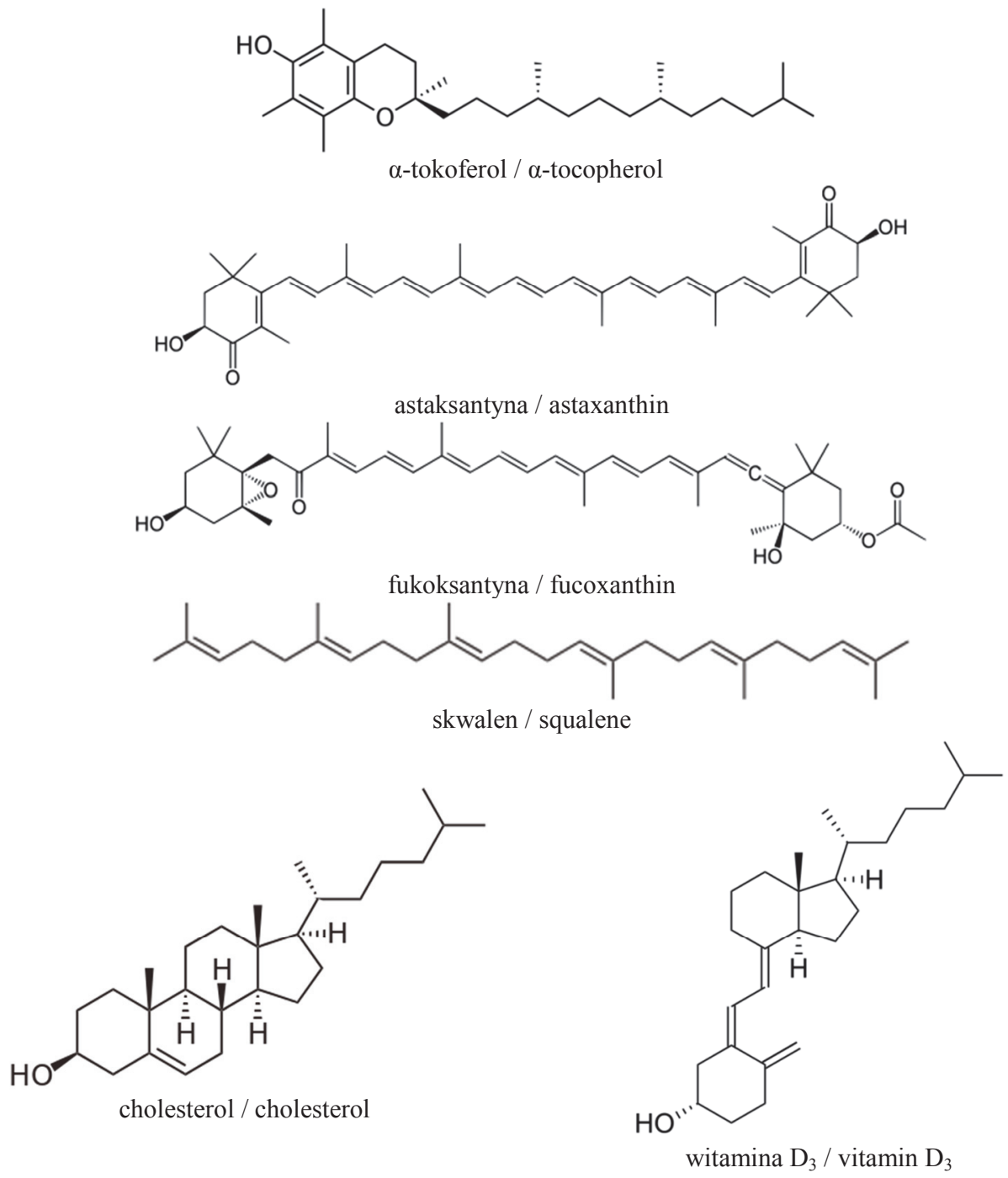

Rys. 2. Wybrane bioaktywne składniki występujące w tkankach ryb

Fig. 2. Selected bioactive compounds found in fish tissues

Cholesterol to związek, którego nadmierne spożycie może prowadzić do rozwoju miażdżycy naczyń krwionośnych, ale jest to także niezbędny składnik w funkcjonowaniu organizmu (rys. 2) jako prekursor hormonów steroidowych, kwasów żółciowych i witaminy $\mathrm{D}_{3}$ (cholekalcyferolu). W mięśniach ryb to główny sterol stanowiący $80 \%$ 
ogólnej zawartości tych związków, a jego stężenie nie jest skorelowane z zawartością tłuszczu w tkankach [34]. W porównaniu jednak z produktami pochodzenia zwierzęcego, mięso ryb morskich uważane jest za stosunkowo ubogie w cholesterol, gdyż zawiera przeciętnie 5-krotnie mniej cholesterolu niż masło $(240 \mathrm{mg} / 100 \mathrm{~g})$ i ok. 20-krotnie mniej niż żółtko jaj (1000 mg/ 100 g) [33].

Do witamin rozpuszczalnych w thuszczach zalicza się również witaminy z grupy $\mathrm{D}$ - ergokalcyferol (witamina $\mathrm{D}_{2}$ ) i cholekalcyferol (witamina $\mathrm{D}_{3}$ - rys. 2), przy czym ten drugi związek chemiczny jest ok. dwa razy bardziej aktywny w porównaniu z witaminą $\mathrm{D}_{2}$. Najważniejszymi źródłami cholekalcyferolu są ryby, a zwłaszcza olej pozyskiwany z wątroby ryb. Witamina $\mathrm{D}_{3}$ reguluje gospodarkę wapniowo-fosforową. Jej niedobory w organizmie mogą prowadzić do krzywicy u dzieci oraz zaburzeń w mineralizacji kości, skutkując osłabieniem ich struktury i zwiększeniem podatności na złamania, co szczególnie widoczne jest $\mathrm{u}$ osób starszych. Witamina $\mathrm{D}_{3}$ syntetyzowana jest przez organizm ludzki w czasie ekspozycji na promieniowanie słoneczne, ale musi być suplementowana w okresach o obniżonym nasłonecznieniu w ciągu dnia, zwłaszcza jesienią i zimą $[15,38]$.

\section{Peptydy przeciwdrobnoustrojowe}

Bioaktywnymi składnikami, które znajdują się także w rybach, są peptydy o działaniu przeciwdrobnoustrojowym, takie jak protaminy i pardaksyna. Protaminy to zasadowe białka o dużej zawartości argininy w składzie aminokwasowym, które zostały zidentyfikowane w jądrach ponad 50 gatunków ryb. Wykazują one aktywność wobec przetrwalników bakterii z rodzaju Bacillus [29]. Pardaksyna to 33-aminokwasowy peptyd wykazujący aktywność przeciwbakteryjną zarówno wobec bakterii Gramdodatnich, jak i Gram-ujemnych. W badaniach prowadzonych przez Huanga i wsp. [10] pardaksyna wspomagała gojenie się ran oraz wpływała na zwalczenie zakażenia metycylinoopornymi bakteriami z gatunku Staphylococcus aureus (ang. methicillinresistant Staphylococcus aureus, MRSA). Ponadto Hu i wsp. [9] wyizolowali peptydy ze skóry tilapii nilowej (Oreochromis niloticus) o ciekawych właściwościach. Polipeptyd o masie mniejszej niż $5 \cdot 10^{3}$ Da był skutecznym i obiecującym środkiem w leczeniu oparzeń i gojeniu się ran, co potwierdzają badania prowadzone na królikach.

\section{Produkty spożywcze i paszowe pozyskiwane z odpadów rybnych}

Odpady pochodzące z zakładów przetwórstwa rybnego obejmują głównie głowy, ości i wnętrzności rybne. W przypadku Japonii, w której konsumpcja ryb i bezkręgowców morskich jest bardzo duża, ilość odpadów szacuje się na ok. $2 \mathrm{mln}$ ton rocznie [42]. W Polsce, z uwagi m.in. na małe spożycie ryb, ta ilość jest prawdopodobnie dużo mniejsza, choć brak jest aktualnych danych obrazujących skalę problemu. Według 
danych z 2011 roku w ciągu roku powstaje ponad 33 tys. ton odpadów rybnych pochodzących tylko z przetwarzania wędzonych łososi na produkty plastrowane [22].

Odpady rybne mogą być wykorzystywane do produkcji hydrolizatów białek. Otrzymuje się je w procesach rozkładu białek do peptydów w wyniku hydrolizy chemicznej kwasowej lub zasadowej czy też enzymatycznej (drogą autolizy lub po dodaniu handlowych preparatów enzymatycznych) $[17,29]$. Hydrolizaty białek rybnych są często wykorzystywane w kuchni azjatyckiej do wyrobu m.in. sosów rybnych i surimi. Pierwszy wyrób produkowany jest w ilości 250 tys. ton rocznie w wyniku spontanicznej fermentacji związków organicznych zawartych w mięsie ryb, które jest mieszane z solą i przechowywane przez 6 - 12 miesięcy. Surimi jest to mielone, rozdrobnione mięso ryb, które przemywa się kilkukrotnie wodą lub roztworami soli, a następnie uzupełnia o odpowiednie krioprotektanty oraz inne dodatki [29].

Światowy wyładunek ryb i owoców morza wynosi ok. $100 \mathrm{mln}$ ton rocznie, z czego $28 \%$ przetwarzane jest na mączkę rybną i olej. Odpady z ryb nienadające się do spożycia mogą zostać przekształcone w składniki podłoży mikrobiologicznych, pasze, mączki rybne i kiszonki, które następnie wykorzystywane są w produkcji zwierzęcej $[5,12,23]$. Mączka rybna jest materiałem paszowym, najważniejszym źródłem białka o wysokiej strawności używanym w żywieniu ryb od wielu lat [12]. Ryby i produkty rybne zawierają białka bogate w niezbędne aminokwasy, takie jak lizyna, metionina i cysteina oraz charakteryzują się większym udziałem tych aminokwasów w $1 \mathrm{~g}$ białka w porównaniu ze wzorcem standardowego białka FAO [38]. Mączki rybne wykorzystywane są także jako pokarm dla mięsożernych zwierząt futerkowych m.in. norek i lisów, a zgodnie z rozporządzeniem Komisji Europejskiej nr 56/2013 [27] stosowanie mączek pochodzenia zwierzęcego jest zabronione w karmieniu przeżuwaczy.

Kiszonki rybne są źródłem białka o wysokiej wartości biologicznej. Mogą być produkowane $\mathrm{z}$ martwych ryb, produktów ubocznych z połowów morskich, odpadów pochodzących z handlu i przemysłu [39]. Powstają w wyniku fermentacji spontanicznej lub po dodaniu odpowiedniej kultury starterowej np. bakterii z gatunku Lactobacillus plantarum. W wyniku aktywności bakterii dochodzi do obniżenia $\mathrm{pH}$ przez syntetyzowany kwas mlekowy, poprawie ulegają cechy sensoryczne oraz wartość odżywcza produktu. Dodatkowo zmniejsza się ilość amin biogennych, które mogą powstawać w rybach z powodu wysokiej zawartości białka [4]. Norwegia jest największym producentem kiszonek z ryb (140 tys. ton rocznie), do produkcji których wykorzystuje produkty uboczne hodowli i przetwórstwa łososia. Zaletą produkcji tego typu pasz są niskie koszty inwestycyjne oraz niewysoka cena produktu gotowego [29].

\section{Biopaliwa pozyskiwane z odpadów rybnych}

Odpady rybne można wykorzystać do produkcji palnego biogazu. Biogaz powstaje w wyniku fermentacji metanowej materii organicznej w warunkach beztlenowych. 
W procesie fermentacji biorą udział bakterie beztlenowe różnych gatunków, a produktem procesów mikrobiologicznych jest gaz składający się głównie z metanu i dwutlenku węgla. Pozostałość po fermentacji wykorzystywana jest jako nawóz organiczny. Salam i wsp. [31] zaproponowali sposób produkcji biogazu w warunkach laboratoryjnych, wykorzystując podroby i skrzela rybne oraz krowie odchody w różnych proporcjach. Zaobserwowano, że w przypadku użycia samych odpadów rybnych wydajność produkcji biogazu wynosiła $0,15 \mathrm{dm}^{3} / \mathrm{kg}$ odpadu, a czas fermentacji wynosił $10 \mathrm{dni}$. W przypadku zastosowania mieszaniny odpadów rybnych i odchodów krowich w stosunku $1: 1,2$ otrzymano $2 \mathrm{dm}^{3}$ gazu/kg odpadów, a czas fermentacji skrócił się do 7 dni.

Innym biopaliwem otrzymywanym z użyciem odpadowych olejów rybnych jest biodiesel, produkowany na drodze transestryfikacji triacylogliceroli niskocząsteczkowym alkoholem np. metylowym lub etylowym. Produktem reakcji są glicerol i estry metylowe (ang. fatty acid methyl esters, FAME) lub etylowe (ang. fatty acid ethyl esters, FAEE) kwasów tłuszczowych. Substratami do produkcji biodiesela mogą być oleje roślinne, tłuszcze zwierzęce i oleje odpadowe [24]. Obecnie prowadzone są próby otrzymywania paliwa typu biodiesel z wykorzystaniem oleju z odpadów przetwórstwa rybnego. Takie badania przeprowadzili m.in. Yahyaee i wsp. [41]. Z 7 kg odpadów pozyskali $768 \mathrm{~g}$ oleju, który został następnie użyty do reakcji transestryfikacji metanolem, katalizowanej wodorotlenkiem potasu, a zgodnie $\mathrm{z}$ wyliczeniami autorów $\mathrm{z}$ jednego $\mathrm{dm}^{3}$ oleju otrzymano $0,9 \mathrm{dm}^{3}$ biodiesela. Uzyskane paliwo charakteryzowało się podobnymi wartościami temperatury zapłonu, lepkości i gęstości co biodiesel produkowany z oleju rzepakowego [41]. Przytoczone badania wskazują na potencjał zagospodarowania odpadowego oleju rybnego do produkcji biodiesela, choć zgodnie z Rozporządzeniem Ministra Energii z dnia 25 maja 2016 r. w sprawie wymagań jakościowych dla biopaliw ciekłych [28] estry metylowe kwasów thuszczowych w swoim składzie nie mogą zawierać więcej niż $12 \%(\mathrm{~m} / \mathrm{m})$ kwasu linolenowego i $1 \%(\mathrm{~m} / \mathrm{m})$ wielonienasyconych kwasów tłuszczowych zawierających co najmniej 4 wiązania podwójne. Dlatego też obecnie odpadowy olej rybny na terenie Polski nie może zostać zagospodarowany w ten sposób.

\section{Podsumowanie}

Obserwuje się wciąż niskie spożycie ryb i przetworów rybnych w Polsce, gdyż surowiec ten jest niedoceniany przez konsumentów, choć niezwykle promowany przez dietetyków i lekarzy. W opracowaniu przedstawiono składniki mięsa ryb oraz rybnych odpadów wykorzystywanych jako dodatki funkcjonalne w technologii żywności oraz kilka przykładów związków bioaktywnych. Obok znanych z pozytywnego wpływu na zdrowie człowieka wielonienasyconych kwasów tłuszczowych z grupy omega-3, zwrócono uwagę na tokoferole, karotenoidy, witaminę $\mathrm{D}_{3}$, skwalen oraz sterole obecne 
w tuszkach rybnych. Wspomniano także o doniesieniach ostatnich lat na temat obecności peptydów przeciwdrobnoustrojowych w mięsie ryb.

Przedstawiono także przykłady wykorzystania stałych i płynnych odpadów przetwórstwa rybnego, które stanowią poważne obciążenie dla środowiska, do produkcji hydrolizatów białkowych, mączek i olejów rybnych czy pasz dla zwierząt. Ze względu na dużą zawartość wody takie odpady są bardziej podatne na zanieczyszczenie drobnoustrojami, a znaczna zawartość tłuszczu czyni je podatnymi na utlenianie. Odpady rybne mogą być wykorzystane wielotorowo. Produktami powstającymi w wyniku zagospodarowania odpadów rybnych są także te o właściwościach dietetycznych, np. chitozan, naturalne barwniki oraz kolagen i żelatyna. Innym kierunkiem zagospodarowania odpadów rybnych może stać się produkcja paliw typu biodiesel i biogaz.

Publikacja została przygotowana w ramach Grantu Wewnętrznego Wydziału Nauk o Żywności Szkoły Głównej Gospodarstwa Wiejskiego w Warszawie pt. „Wykorzystanie właściwości lipolitycznych drożdży Yarrowia lipolytica do waloryzacji odpadowego oleju po procesie wędzenia ryb".

\section{Literatura}

[1] Adamska A., Rutkowska J., Białek M.: Charakterystyka i właściwości prozdrowotne wybranych karotenoidów występujących w rybach i skorupiakach. Probl. Hig. Epidemiol., 2014, 95 (1), 36-40.

[2] Arciszewska A.: Wykorzystanie ryb w technologii gastronomicznej. W: Wybrane zagadnienia z technologii żywności. Red. M. Mitek, M. Słowiński. Wyd. SGGW, Warszawa 2006, ss. 447-457.

[3] Bordajandi L.R., Gomez G., Fernandez M.A., Abad E., Rivera J., Gonzalez M.J.: Study on PCBs, $\mathrm{PCDD} / \mathrm{Fs}$, organochlorine pesticides, heavy metals and arsenic content in freshwater fish species from the River Turia (Spain). Chemosphere, 2003, 53, 163-171.

[4] Dapkevicius M.L.N.E., Nout M.J.R., Rombouts F.M., Houben J.H., Wymenga W.: Biogenic amine formation and degradation by potential fish silage starter microorganisms. Int. J. Food Microbiol., 2000, 57, 107-114.

[5] Fabiszewska A., Pielińska A., Mazurczak P., Zieniuk B., Wołoszynowska M.: Wpływ wybranych czynników na wydajność ekstrakcji i skład kwasów thuszczowych oleju mikrobiologicznego otrzymywanego z komórek drożdży Yarrowia lipolytica. Żywność. Nauka. Technologia. Jakość, 2017, 24, 1 (110), 59-69.

[6] GUS: Rocznik Statystyczny Gospodarki Morskiej 2010. Zakład Wydawnictw Statystycznych, Warszawa 2010.

[7] GUS: Rocznik Statystyczny Gospodarki Morskiej 2016. Zakład Wydawnictw Statystycznych, Warszawa 2016.

[8] GUS: Rocznik Statystyczny Przemysłu 2016. Zakład Wydawnictw Statystycznych, Warszawa 2016.

[9] Hu Z., Yang P., Zhou C., Li S., Hong P.: Marine collagen peptides from the skin of Nile tilapia (Oreochromis niloticus): Characterization and wound healing evaluation. Marine Drugs, 2017, 15 (102), 1-11.

[10] Huang H.-N., Pan C.-Y., Chan Y.-L., Chen J.-Y., Wu C.-J.: Use of the antimicrobial peptide pardaxin (GE33) to protect against methicillin-resistant Staphylococcus aureus infection in mice with skin injuries. Antimicrobial Agents and Chemotherapy, 2014, 58 (3), 1538-1545. 
[11] Jaka ryba na obiad? Poradnik konsumenta o rybach i owocach morza.[on line]. WWF Polska. Dostęp w Internecie [25.07.2017]: http://ryby.wwf.pl/jaka-ryba-na-obiad-poradnik-konsumenta

[12] Jayathilakan K., Sultana K., Radhakrishna K., Bawa A.S.L: Utilization of byproducts and waste materials from meat, poultry and fish processing industries: A review. J. Food Sci. Technol., 2012, 49 (3), 278-293.

[13] Karim A.A., Bhat R.: Fish gelatin: Properties, challenges, and prospects as an alternative to mammalian gelatins. Food Hydrocoll., 2009, 23, 563-576.

[14] Kidd P.M.: Astaxanthin, cell membrane nutrient with diverse clinical benefits and anti-aging potential. Alternative Medicine Review, 2011, 16 (4), 355-364.

[15] Kołodziejczyk A.: Naturalne związki organiczne. Wyd. Nauk. PWN, Warszawa 2013.

[16] Kopicova Z., Vavreinova S.: Occurrence of squalene and cholesterol in various species of Czech freshwater fish. Czech J. Food Sci., 2007, 25, 195-201.

[17] Kristinsson H.G., Rasco B.A.: Fish protein hydrolysates: Production, biochemical, and functional properties. Crit. Rev. Food Sci. Nutr., 2000, 40 (1), 43-81.

[18] Łątkowska M., Wołosiak R.: Zawartość tokoferoli w tuszkach oraz zalewach wybranych konserw rybnych. Bromat. Chem. Toksykol., 2012, XLV (3), 852-857.

[19] Marciniak M.: Analiza i ocena zmian w polskiej gospodarce rybnej po akcesji do Unii Europejskiej. Zesz. Nauk. SGGW. Problemy Rolnictwa Światowego, 2009, 7 (22), 70-79.

[20] Marciniak-Łukasiak K., Krygier K.: Charakterystyka kwasów omega 3 i ich zastosowanie w żywności funkcjonalnej. Przem. Spoż., 2004, 12, 32-36.

[21] Marcotrigiano G.O., Storelli M.M.: Heavy metal, polychlorinated biphenyl and organochlorine pesticide residues in marine organisms: Risk evaluation for consumers. Veter. Res. Comm., 2003, 27 Suppl. 1, 183-195.

[22] Mazur K., Kołodziej K., Kołodziejski W.: Ocena przydatności technologicznej odpadowych skór z łososi do pozyskiwania z nich oleju rybnego metodą tłoczenia. Żywność. Nauka. Technologia. Jakość, 2011, 4 (77), 151-159.

[23] Mazurczak P., Zieniuk B., Fabiszewska A., Nowak D., Wołoszynowska M., Białecka-Florjańczyk E.: Utylizacja odpadów pochodzących z zakładów przemysłu spożywczego i paliwowego z wykorzystaniem lipolitycznych drożdży Yarrowia lipolytica. Zesz. Probl. Post. Nauk. Roln., 2017, 588, $15-24$.

[24] Meng X., Yang J., Xu X., Zhang L., Nie Q., Xian M.: Biodiesel production from oleaginous microorganism. Renewable Energy, 2009, 34, 1-5.

[25] Mirowski A., Jachnis A.: Kwas dokozaheksaenowy - składnik odżywczy o kluczowym znaczeniu w okresie ciąży. Część I. Niedobór kwasu dokozaheksaenowego. Życie Weter., 2016, 91 (12), 922923.

[26] Norziah M.H., Al-Hassan A., Khairulnizam A.B., Mordi M.N., Norita M.: Characterization of fish gelatin from surimi processing wastes: Thermal analysis and effect of transglutaminase on gel properties. Food Hydrocoll., 2009, 23, 1610-1616.

[27] Rozporządzenie Komisji (UE) nr 56/2013 z dnia 16 stycznia 2013 r. zmieniające załączniki I i IV do rozporządzenia Parlamentu Europejskiego i Rady (WE) nr 999/2001 ustanawiającego zasady dotyczące zapobiegania, kontroli i zwalczania niektórych przenośnych gąbczastych encefalopatii. Dz. Urz. UE L 21, ss. 3-16, z 24.01.2013.

[28] Rozporządzenie Ministra Energii z dnia 25 maja 2016 r. w sprawie wymagań jakościowych dla biopaliw ciekłych. Dz.U. 2016 r., poz. 771.

[29] Rustad T.: Utilisation of marine by-products. EJEAFChe, 2003, 2 (4), 458-463.

[30] Ruxton C.H.S., Reed S.C., Simpson M.J.A., Millington K.J.: The health benefits of omega-3 polyunsaturated fatty acids: A review of the evidence. J. Hum. Nutr. Diet., 2004, 17 (5), 449-459.

[31] Salam B., Islam M., Rahman M.T.: Biogas from anaerobic digestion of fish waste. Proc. Int. Conf. on Mechanical Engineering 2009, Dhaka, Bangladesh 2009, December, 26-28, pp. 1-3. 
[32] Von Schacky C., Harris W.S.: Cardiovascular benefits of omega-3 fatty acids. Cardiovascular Research, 2007, 73, 310-315.

[33] Sikorski Z.E.: Ryby i bezkręgowce morskie. Pozyskiwanie, właściwości i przetwarzanie. WNT, Warszawa 2004.

[34] Stanek M., Dąbrowski J., Roślewska A., Janicki B.: Ocena zawartości tłuszczu i cholesterolu w mięsie samic oraz samców okonia (Perca fluviatilis L.) z Jeziora Gopło. Folia Pomer. Univ. Technol. Stetin. Agric., Aliment. Pisc., Zootech., 2009, 271 (10), 5-10.

[35] Swanson D., Block R., Mousa S.A.: Omega-3 fatty acids EPA and DHA: Health benefits throughout life. Adv. Nutr., 2012, 3, 1-7.

[36] Syvaoja E.-L., Salminen K., Piironen V., Varo P., Kerojoki O., Koivistoinen P.: Tocopherols and tocotrienols in finnish foods: Fish and fish products. JAOCS, 1985, 62 (8), 1245-1248.

[37] Szlinder-Richter J., Usydus Z., Malesa-Ciećwierz M., Polak-Juszczak L., Ruczyńska W.: Marine and farmed fish on the Polish market: Comparison of the nutritive value and human exposure to PCDD/Fs and other contaminants. Chemosphere, 2011, 85, 1725-1733.

[38] Usydus Z., Szlinder-Richter J.: Functional properties of fish and fish products: A review. Int. J. Food Prop., 2012, 15 (4), 823-846.

[39] Vidotti R.M., Viegas E.M.M., Carneiro D.J.: Amino acid composition of processed fish silage using different raw materials. Anim. Feed Sci. Technol., 2003, 105, 199-204.

[40] Waszkiewicz-Robak B., Świderski F.: Hydrokoloidy pochodzenia roślinnego jako zamienniki żelatyny. Bezpieczna Żywność, 2001, 1, 31-37.

[41] Yahyaee R., Ghobadian B., Najafi G.: Waste fish oil biodiesel as a source of renewable fuel in Iran. Renewable and Sustainable Energy Reviews, 2013, 17, 312-319.

[42] Yano Y., Oikawa H., Satomi M.: Reduction of lipids in fish meal prepared from fish waste by a yeast Yarrowia lipolytica. Int. J. Food Microbiol., 2008, 121, 302-307.

\section{FISH AND FISH WASTES AS SOURCE OF BIOACTIVE COMPOUNDS AND RAW MATERIAL FOR ENERGY INDUSTRY}

$$
\text { S u m m a ry }
$$

The objective of the study was to characterize fish meat and fish industry waste as a source of valuable nutritional components and raw material for energy industry. Fish meat and fish products are an important element of the diversified diet. Fish and fish wastes can be a source of omega-3 polyunsaturated fatty acids: docosahexaenoic acid (DHA) and eicosapentaenoic acid (EPA), i.e. of the compounds that have positive effects on human body. Functional additives from fish are often used in the food technology, such as fish gelatine that differs from pork gelatine in its physical-chemical properties, fat-soluble vitamins, and carotenoid pigments with antioxidant effects. Peptides can be isolated from fish; they have antimicrobial effects on various species of Gram-positive and Gram-negative bacteria. In the study, a possibility has been shown of using fish wastes from the fish industry to produce valuable nutritional components. In addition to the use of fish wastes in the production of fish feed and meals, fish oils and silages as well as protein hydrolysates utilized as spices in the Asian cuisine, it is possible to use those fish wastes as a raw material for the energy industry, among other things in the production of biodiesel - a type of liquid fuel and in the production of biogas. Also, safety aspects have been discussed of consuming fish, which may contain harmful lipophilic organic compounds and heavy metals accumulated by those animals in their natural living environment, i.e. in the contaminated freshwater and in salty waters.

Key words: fish, fish waste, PUFA (polyunsaturated fatty acids), bioactive components, biodiesel, biogas 䙢 